\title{
ELSINA ELISABETH LATUHERU: MENGHIDUPKAN PERDAMAIAN MEMBANGUN KEMANUSIAAN DI BUMI AMBON
}

\author{
Moh. Shofan
}

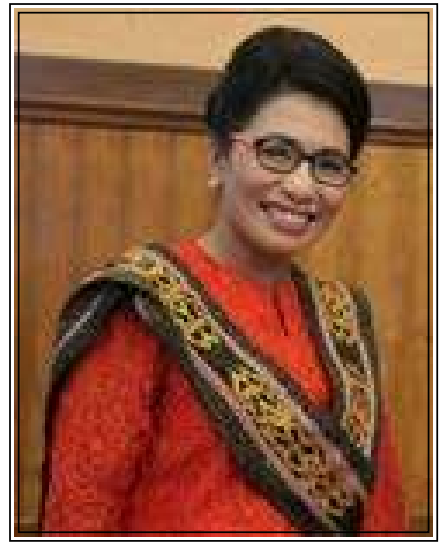

\section{Elsina Elisabeth Latuheru}

Elsina Elisabeth Latuheru-yang akrab dipanggil Elsye-adalah seorang aktivis Kopi Badati yang bergerak dalam dialog perdamaian lintas komunitas berbeda agama untuk membangun relasi kemanusiaan. Gerakan ini melakukan provokasi kepada masyarakat agar mengkontribusikan apa saja yang bisa menciptakan perdamaian. Mereka juga memutar film "The Imam and The Pastor" di

wilayah perbatasan dan mendiskusikannya serta membuat khutbah-khutbah damai (peace sermons). Film ini sangat tepat untuk konteks Ambon yang selama ini dilanda konflik antar-agama (Muslim-Kristen). Ini bukan tema mudah, karena agama lebih sering dirujuk sebagai sumber kekerasan. Tetapi realitas menunjukkan bahwa berita soal kekerasan agama justru terjadi di kota ini: Ambon. Karenanya, film ini sangat tepat digunakan sebagai alat untuk memediasi pihak-pihak yang berkonflik atau sebagai langkah antisipatif terhadap konflik antar-agama. Film ini juga sebagai alat mediasi untuk melakukan dialog antar-iman. Film yang ditonton oleh ratusan peserta yang berlatar beda agamaMuslim-Kristen-ini memberikan pemahaman dan pengertian bahwa konflik atas nama apapun tidaklah bisa dibenarkan, bukan hanya kerugian material, 
tetapi lebih dari sekadar itu konflik telah menyebabkan tercerabutnya nilai-nilai kemanusiaan universal yang dijunjung tinggi oleh nilai-nilai luhur agama.

Berkat gerakan "provokator damai" ini, sekarang telah muncul kesadaran kolektif pada masyarakat Ambon untuk bersama-sama menciptakan perdamaian. Untuk tujuan mulia itu, Elsye, juga terlibat dalam program pelatihan Living Values Education (LVE) sebagai media untuk mempromosikan perdamaian. LVE adalah program pendidikan nilai yang menawarkan pelatihan, metodologi praktis bagi para pendidik, fasilitator, orangtua dan pendamping anak untuk membantu mereka menyediakan kesempatan bagi anak-anak dan anak muda untuk menggali dan mengembangkan nilai-nilai universal serta mengasosiasikan keterampilan sosial dan emosional intrapersonal serta interpersonal. Dua belas nilai yang diajarkan LVE adalah ; Cinta, Kerendahan Hati, Kejujuran, Kerjasama, Menghargai, Kesederhanaan, Toleransi, Tanggugjawab, Kedamaian, Kebebasan, Kebahagiaan, dan Persatuan. LVE dikenalkan sejak 1995 oleh Yayasan Studi Spiritualitas Brahma Kumaris, yang mendapat dukungan dari UNESCO. Hingga Maret tahun 2000, tercatat 1800 lokasi di 64 negara telah mengaplikasikannya. Hasilnya adalah Living Values Education.

Elsye yang lahir di bumi Ambon, 12 Maret 1973 ini pertama kali mengenal LVE pada tahun 2010 atas ajakan temannya. Sejak mengenal LVE melalui beberapa pelatihan yang telah diikutinya, ia merasa bahwa ini merupakan kesempatan yang luar biasa, karena pelatihan seperti inilah yang selama ini dicarinya dalam rangka proses kerja untuk perdamaian di Maluku sejak awal kerusuhan. Melalui LVE, Elsye merasa mengenal lebih dekat nilai-nilai kehidupan, seperti kedamaian, kejujuran, cinta-kasih, dan sebagainya. Nilai-nilai tersebut menurutnya akan menjadi sebuah standarisasi yang mengarahkan perilaku manusia untuk berkembang, memelihara sikap terhadap obyek dan situasi yang relevan serta mengarahkan seseorang dalam berbuat kebaikan.

Lebih jauh, Elsye-sarjana lulusan Universitas Pattimura jurusan Ilmu dan Teknologi Kelautan-mengatakan bahwa meskipun fokus LVE lebih pada menghidupkan 12 nilai universal, tetapi dalam implementasinya selalu saja ada sesuatu yang baru yang dapat dipakai untuk menjawab kebutuhan hidup manusia. Dari keseluruhan dua belas nilai yang terkandung dalam LVE, ia lebih memusatkan perhatian pada nilai kedamaian, tanpa menafikan atau mengabaikan nilai-nilai lainnya. Hal itu bukan karena ia hidup di daerah konflik, tetapi lebih kepada bagaimana menghidupkan nilai damai dalam diri sendiri, sebab tak jarang justru konflik dengan diri sendiri, dengan masa 
lalu atau lingkungan (justru) bersumber dari diri sendiri. Dan itu, lanjutnya, menjadi penghalang untuk tumbuhnya nilai-nilai yang lain.

Dengan langkah-langkah praktis yang dilakukannya selama ini, misalnya, menyebut beberapa nilai, "saya damai”, "saya tenang”, “saya bijaksana”, "saya lemah lembut", ternyata itu memberikan warna tersendiri dan mempengaruhi hampir di setiap seluruh aktivitasnya. Begitupun ketika ada masalah ia punya reaksi yang berbeda karena ia sedang mengulang dan memfokus serta mengingat nilai yang harus dihidupkan. Elsye juga merasa lebih tenang, lebih ringan hidupnya dibandingkan misalnya ketika apa yang telah diperbuatnya dulu untuk membuat sebuah perubahan. Tetapi ketika melihat kembali ke LVE satu hal yang ia tangkap dan rasakan adalah bahwa ia tidak bisa mengubah hidup orang lain, kecuali mengubah diri sendiri. Dan ternyata apa yang dilakukannya membuat lingkungan berubah. "Bagaimana kita mau disebut sederhana dan bertanggungjawab kalau misalnya dalam diri kita tidak ada perasaan tenang atau damai”, terangnya.

Kedamaian batin, menurut Elsye, tercermin dalam keseimbangan emosi. Dalam hidup pasti ada naik turun, fluktuasi, tetapi jika seseorang damai dalam batinnya, ia bisa stabil, menyeimbangkan diri. Sebab itu, lanjut Elsye, untuk bisa menerima orang yang berbeda kita perlu memahami bahwa setiap orang itu unik, karena memiliki misi hidup yang berbeda dari kita. Sebab lain kita sulit menerima orang lain ialah karena kita selalu punya harapan/tuntutan terhadap orang lain. Saat orang lain tidak bisa memenuhi harapan kita, kita menolak kehadiran mereka.

Sebagai aktivis perdamaian, Elsye melihat bahwa LVE sangat relevan jika diterapkan di daerah konflik, seperti Ambon, karena bisa membangun dialog antaragama-Muslim dan Kristen. Elsye sendiri seringkali pergi ke kampung yang dihuni mayoritas Muslim, dan tidak ada masalah. Bahkan, menurut Elsye, para pemeluk agama juga bisa saling tukar tempat, orang-orang Muslim ke Kristen, dan orang Kristen ke Muslim, sehingga dengan demikian, tidak ada halangan-halangan mental.

Selama ini, kata Elsye, kegiatan LVE ini selalu dilakukan, baik dalam bentuk kegiatan formal yang dilakukan dengan program maupun kegiatan nonformal, seperti kegiatan keagamaan atau kegiatan-kegiatan umum lainnya yang dilakukan di masyarakat. Saat pelatihan, teknik perkenalan dilakukan secara berbeda dengan cara-cara yang digunakan sebelumnya. Setiap peserta menaruh satu lebel nilai di belakang nama masing-masing orang, misalnya Elsye Elegan, 
Elsye Tulus, dan sebagainya. Ini sesuatu yang istimewa karena memberikan antusias dan gairah dalam kehidupan. Model seperti ini, menurut Elsye sangat cocok diterapkan di lingkungan anak-anak, dan juga menarik karena dengan begitu setiap orang bisa menghargai diri sendiri. Dan ketika pendekatan seperti ini dilakukan dalam aktivitas sehari-hari, baik dalam berorganisasi atau bermasyarakat akan terasa terlihat berbeda. Mereka lebih terbuka, ingin tahu, dan bisa turut dalam proses-proses selanjutnya.

Jadi, menurut Elsye, dengan menggunakan pendekatan LVE, mereka bereaksi sangat positif, dibandingkan misalnya ketika menggunakan pendekatan agama. Elsye menceriterakan pengalamannya saat memberikan stimulus dengan menggunakan pendekatan agama, di mana setiap orang beragama tidak boleh membenci satu sama lain karena ajaran Tuhan dalam Kitab SuciNya mengatakan demikian. Kalau ada orang menampar pipi kanan kita maka kita harus memberikan pipi kiri. Namun, lanjut Elsye, seperti ini justru sulit diterima. Kita bisa membenci seseorang sehingga kita menjadi buta dengan sisisisi baik yang mereka miliki. Kita lupa bahwa seseorang itu buruk di mata kita bukan karena orang lain itu tidak punya sisi baik sama sekali. Justru, menurut Elsye, yang patut dikasihani ialah kita yang tidak bisa menemukan kebaikan dalam diri orang lain.

Nah, dengan pendekatan LVE, demikian Elsye, semua manusia itu sama dan mempunyai kebutuhan yang sama, rasa aman yang sama. Bagaimana berinteraksi dengan orang-orang yang berada di sekeliling kita, bagaimana tumbuh kesadaran positif: peduli, memahami, menghargai, menghormati. Hubungan timbal-balik antara diri kita yang berkesadaran (faktor internal) dan lingkungan luar (faktor eksternal), menurutnya tak bisa diabaikan. Keduanya saling memberikan stimulus yang dapat saling mendorong bahkan saling mempengaruhi untuk melakukan tindakan yang bernilai. Bila kebutuhan ini (bernilai, dihargai, dipahami, dicintai, dan lain-lain) terpenuhi, lanjut Elsye, maka akan tercipta kehidupan yang lebih baik dan setiap orang memandang yang lain bukan karena latar belakang perbuatannya tetapi latar belakang nilainilai universal yang ada padanya.

Elsye mengandaikan jika pada setiap orang tidak ada lebel agama, suku, maka semua manusia adalah sama. Inilah yang menurutnya harus menjadi dasar untuk banyak hal tentang perdamaian bisa terjadi. "Yang membuat kita berbeda dan membuat kekacauan ketika kita menaruh lebel dia laki-laki saya perempuan, dia boleh begini, sementara saya tidak boleh begitu, ketika merasa 
tidak adil maka timbullah masalah. Tetapi kalau kita semua adalah sebuah jiwa, kebutuhan kita sama, kita bisa berkontribusi yang sama, maka tidak akan ada kata beda”, jelas Elsye.

Selama terjun dalam pelatihan LVE, Elsye banyak mendengar pengalaman dari mereka yang sangat beragam. Secara umum, mereka mengalami perubahan positif. Selama proses pembongkaran pribadi ini, peserta tampaknya diekspos pada keadaan yang mungkin "esktrem". Ada peserta yang terhanyut dalam keharuan mendalam, yang membuatnya terisak-isak. Di setiap akhir dari aktivitas LVE mereka merasakan bahwa ini sangat bermanfaat sekali dan menjadi kebutuhan setiap orang, mereka merasa ini yang seharusnya mereka lakukan dan butuhkan. Inilah yang membedakan antara pendekatan LVE dengan pendekatan agama yang dulu pernah dilakukannya.

Elsye melihat manfaat LVE tergantung seberapa besar kita menggunakannya untuk memberikan sebanyak mungkin manfaat kepada diri sendiri dan terhadap sesama. Dengan LVE yang sudah dilakukannya, setidaknya ada dua manfaat: pertama, gaya bahasa sudah berubah menjadi lebih baik, dan kedua, pendekatan komunikasi, yakni lebih banyak mendengar aktif daripada berfikir memberikan solusi apa. Memberikan solusi adalah kebutuhan kedua, setelah ia merasa bahwa dia didengar dulu, karena terkadang ia sebenarnya tahu apa yang harus dia lakukan, tetapi satu hal yang tidak boleh lupa ialah kebutuhan dia adalah untuk didengar. Seperti itu, lanjut Elsye, komunikasi bisa lebih dalam, dan ketika komunikasi bisa lebih dalam maka disitulah akan ditemukan inti masalah dan kebutuhan komunitas orang itu apa. Itu semua menurutnya dimulai dari perubahan pada diri sendiri. "Ketika kita memberi dari hati, kita melakukan-nya bersumber dari kegembiraan yang muncul kapanpun kita bersedia memperkaya kehidupan orang lain. Fokus pada hati bukan mulut", begitu pesan singkat di salah satu status facebooknya.

Menurut Elsye, dari sekian banyak materi yang ada dalam LVE ia lebih memilih ke arah bagaimana menggali dan menghidupkan nilai, karena ternyata dalam beberapa aktivitas yang diikutinya orang cenderung tidak melihat banyak hal sisi baik dalam kehidupan. Hal ini, menurutnya tidak lepas dari pengaruh akibat kerusuhan, di mana mereka terserang virus hal-hal yang bersifat negatif, seperti rasa kebencian terhadap mereka yang berbeda dalam agama, dan ini seolah sudah menjadi habit. Ia teringat bagaimana dulu orang tua sangat survive hidup di daerah kepulauan dengan teknologi yang kurang memadai. Mereka bisa saling berbagi ketika mereka menyeberang pulau dan terdampar di 
suatu tempat karena tidak ada alat transportasi. Akhirnya mereka harus hidup di komunitas yang baru dan komunitas itu menerima dengan baik sehingga terjalinlah ikatan pela. Artinya ada budaya percaya kepada orang lain, menerima dan menghargai orang lain. Jika mengingat dan menghidupkan itu, tegas Elsye, akan sangat berbeda ketika melihat konflik yang penuh dengan kecurigaan. Tradisi luhur seperti ini yang seharusnya dihidupkan kembali. Yang kedua adalah membangun dan merumuskan mimpi. Jika tidak ada inisiatif untuk keluar dari Maluku, maka besar kemungkinan mereka akan diperhadapkan dengan kondisi yang hancur, tidak ada harapan.

Sebagai orang yang sangat concern dengan gerakan perdamaian, Elsye tidak sekadar mengenal dengan baik LVE dan bagaimana menerapkannya di berbagai komunitas dan lembaga pendidikan. Ia pun memperdalam lagi nilai-nilai kehidupan dengan mengikuti pelatihan "Peace of Mind" di Brahma Kumaris University, Mount Abu, Rajasthan, India, selama 10 hari. Ia dikirim ke India atas rekomendasi dari Helen Quirin-the LVE National Coordinator for Indonesia. Pelatihan ini diikuti oleh mereka yang berasal dari beragam latar belakang, tingkat pendidikan, pekerjaan dan usia. Salah satunya adalah Elsye yang berkeinginan untuk berpartisipasi secara aktif dalam proses perubahan melalui perkembangan pribadi berdasarkan ilmu spiritual dan praktek meditasi.

Mengikuti pelatihan selama sepuluh hari, Elsye merasa belajar lebih dalam serta mendapatkan banyak hal yang luar biasa, di antaranya adalah kedamaian pikiran (peace of mind) sebagai satu jalan hidup. Ia ingin bisa mengembangkan diri secara optimal, dan lebih siap dalam menghadapi tantangan hidup. Ia mengatakan bahwa dalam iman orang yang setia merenungkan firman Tuhan apa saja yang diperbuatnya akan berhasil. Dengan memberikan waktu untuk Tuhan dan diri kita sendiri, maka di situlah sesungguhnya ada kekuatan yang luar biasa. Pasca pelatihan di India, ia lebih banyak melakukan penghayatan dan menghidupkan nilai-nilai LVE.

Elsye tertarik dengan dunia perdamaian sejak ia masih kecil. Saat masuk sekolah dasar hingga mengenyam bangku kuliah selalu ada keinginan untuk hidup yang lebih baik. Masa-masa kuliah ia habiskan waktu dengan mengikuti sejumlah kegiatan, misalnya dengan mengikuti lomba karya ilmiah sampai pada tingkat nasional. Mengingat masa-masa itu, ia mengatakan, "Ketika kita ingin sesuatu yang lebih baik dalam hidup kita dan kita tidak mendapatkan itu, maka timbullah masalah. Tetapi apakah kita akan tetap diam atau kita mencoba melewati suatu masalah supaya mendapatkan tujuan kita. Jadi, singkat kata: 
tujuan hidup saya adalah membuat orang lain tersenyum”.

Elsye begitu sangat menyesalkan mengapa pendidikan di Indonesia masih tetap berorientasi pada capaian-capaian kognitif dan mengabaikan aspek lainnya: afektif dan psikomotorik. Dalam segi praktis ia sering bertanya mengapa ia lebih banyak menghabiskan waktu sekolah-SD 6 tahun, SMP 3 tahun, SMA 3 tahun, S-1 4-5 tahun-selama kurang lebih 17 tahun. Produk dari 17 tahun menurutnya merupakan waktu yang cukup lama. Tetapi apa yang terjadi adalah ia hampir lupa semua proses yang telah dilaluinya selama masa itu, setidaknya dalam segi pengetahuan. Karena menurutnya yang dibutuhkan dalam kehidupan selanjutnya adalah bukan saja 2 × 2 atau $\mathrm{f}: \mathrm{x}=>$ $\mathrm{ax}+\mathrm{b}$ tetapi lebih ke arah skill kehidupan di mana itu tidak banyak diajarkan kecuali sedikit sekali yang ia masih ingat, misalnya saat di mana ketika aktif di ketua OSIS, Pramuka, dan lain-lain. Itulah yang menjadi hal-hal dasar untuk dia bisa lebih tidak never give up, tetapi lebih daripada itu kontribusinya tidak terlalu banyak.

Kini, sejalan dengan perkembangan zaman, Elsye melihat anak-anak yang sedang belajar berjuang dengan kondisi kehidupan yang sangat kompleks. Artinya 17 tahun proses belajar itu tidak memberikan dampak yang lebih dan suatu proses kehidupan awal harus dimulai lagi. Tetapi nyatanya itu tidak didapat karena mereka berada dalam lingkungan yang rusak. Sehingga, lanjut Elsye, boleh dikatakan di sini bahwa dunia pendidikan di Indonesia saat ini, harusnya lebih menyentuh untuk bagaimana menghidupkan nilai yang menjadi modal untuk dia bisa melanjutkan hidup sampai dia meninggal. Dan menurutnya, pendidikan yang paling mendesak dilakukan saat ini adalah pendidikan nilai.

Dengan pelatihan LVE, semua orang yang terlibat dalam pelatihan itu, menurut Elsye sepakat memikirkan bagaimana pelatihan pendidikan di Ambon bisa memberikan dampak positif dan kembali kepada nilai-nilai jati diri orang Ambon, kembali hidup bersaudara. Namun demikian, selama pelatihan dan pendampingan LVE di Ambon, tidak bisa dipungkiri bahwa banyak tantangan, di antaranya kegagalan guru dalam menumbuhkan sikap kebinekaan, toleransi, saling menghargai, dan lain-lain.

Tantangan lain adalah metode pendidikan menghidupkan nilai belum banyak dilakukan oleh para guru di wilayah Ambon. Untuk itu diperlukan pelatihan LVE untuk mensosialisasikan metode pelatihan ini, sehingga ditemukan metode yang relevan karena mendorong perdamaian di samping keterlibatan 
seluruh komponen masyarakat di setiap proses pembangunan merupakan aspek yang sangat penting. [] 